\title{
Determinants of financing constraints
}

\author{
Anabela Santos $(\mathbb{D} \cdot$ Michele Cincera
}

Accepted: 11 January 2021 / Published online: 25 January 2021

(C) The Author(s) 2021

\begin{abstract}
Using a recursive bivariate probit model and survey data covering the period 2014-2018, the present paper aims to assess which factors in the financial market (supply side) have a higher impact on firms' likelihood to be financially constrained. The results show that after controlling for potential endogenous bias due to unobservable firm characteristics, being an innovative firm increases the probability of being financially constrained between 21 and $32 \%$. The nature of the innovation strategy also seems to influence the severity of financing constraints. For financially constrained firms, the main factors that limit future financing for growth ambitions are the lack of collateral, bureaucracy, and too high a price. Findings also indicate that measures to facilitate equity investments and making existing public measures easier are the most important factors for future financing while tax incentives only play a minor role.
\end{abstract}

Keywords Financing · Innovation · European Union

JEL classifications $\mathrm{O} 16 \cdot \mathrm{O} 31 \cdot \mathrm{O} 52 \cdot \mathrm{L} 26$

\footnotetext{
A. Santos $(\bowtie)$

European Commission, Joint Research Centre, Sevilla, Spain

e-mail: anabela.marques-santos@ec.europa.eu

M. Cincera

Université libre de Bruxelles, iCite, ECARES, Brussels, Belgium e-mail: Michele.Cincera@ulb.be
}

\section{Introduction}

Joseph Schumpeter (1934) was the first to defend that financial intermediaries in the capital market are essential for innovation and economic growth. However, due to asymmetric information between entrepreneurs and investors, several firms are faced with financing constraints. Usually, innovative firms are more financially constrained than non-innovative ones (Belin et al. 2011; Bah and Dumontier 2001; Aghion et al. 2004). Indeed, in addition to the problem of asymmetric information, innovative firms have fewer collateralizable assets (Hall and Lerner 2010) because "the capital created by R\&D is largely intangible ${ }^{1}$ and firm-specific, limiting its resale market value" (Hall 2009:11). This situation could be associated with a higher risk for lenders if the firm has not enough valuable collateral since, in the case of nonpayment of the debt by the borrower, the investor's loss is also higher. For this reason, lenders generally request higher collateral, in order to reduce their loss and considering the observed-risk hypothesis (Blazy and Weill 2013). So due to uncertainty and risk, financial institutions are reluctant to invest in $\mathrm{R} \& \mathrm{D}$ projects compared to more traditional business projects (Mazzucato 2013).

Financing constraints have been highlighted by many authors (Canepa and Stoneman 2008; Iammarino et al. 2009) as a significant obstacle to innovation, but the degree of exposure to this problem is not homogeneous among firms. The identification of constrained firms is

\footnotetext{
${ }^{1}$ Most expenditure (50\% or more) on R\&D investment goes toward paying scientists and engineers' salaries (Hall 2009).
} 
particularly important for policymakers in order to design effective policy orientation and to give public support to firms most in need (Hottenrott and Peters 2012).

The present paper focuses on direct assessment of financing constraints through the anonymous survey on SMEs' access to finance in the euro area (SAFE), undertaken together by the European Commission and the European Central Bank (ECB).

Using a recursive bivariate model, where the first equation is to demonstrate an innovative behavior and the second to be a financially constrained firm, the paper aims to (i) identify which factors, both internal and external to the firm, have a higher impact on hindering access to finance; and (ii) assess how far innovative behavior (strategy and typology) can induce financing constraints. On the other hand, the present study also aims to assess differences between innovative firms and non-innovate ones, as regards firms' perception about the characteristics of the supply side of the financial market. The study centers on European SMEs that have growth ambitions and therefore need external finance since information about obstacles is only available for this group of firms.

The contribution and originality of the paper are based on the inclusion in the model of variables related to firms' external factors and linked with financial market characteristics, considered limiting as regards obtaining finance for growth ambitions. Indeed, most studies carried out have focused more on firms' characteristics or countries' institutional factors as the main determinants of firms' financing constraints. However, the paper intends to go further and assess which constraints on the supply side lead to financing constraints. Difficulties in access to finance have been highlighted as an important obstacle to innovative activities, but the reverse relationship remains little explored. Finally, we use a data source (SAFE) that, as far as we are aware, has not previously been used to this end.

The paper is structured as follows. "Section 2" presents the theoretical framework of the study. "Section 3" describes the database. "Section 4" defines the conceptual framework and methodology. "Section 5" presents the results. "Section 6" concludes and provides some policy recommendations.

\section{Background theory and literature review}

From the corporate finance perspective, the decision to invest depends on the price or cost of such an investment and the required rate of return. The neo-classical longrun model of Jorgenson (1963) explains that the investment demand or the desired amount of capital stock is a function of a firm's output and of user capital cost, where the output takes into account the price and quantity of goods and services, and the user capital cost is estimated taking in the rate of taxation, interest rate, and rate of investment replacement. Furthermore, the cost of capital is also determined by a firm's capital structure, i.e., a mix between internal and external (debt and equity) financing. According to the Modigliani and Miller (1958) theorem, internal and external sources of financing are perfect substitutes. However, the main limitations of this hypothesis lie in the authors' assumptions regarding perfect markets (without asymmetric information, risk, uncertainty, taxes, and bankruptcy costs) and the same cost of capital irrespective of financing sources and investment type (Damodaran 2006; Hall and Lerner 2010). Indeed, there are several reasons why internal and external financing sources not perfect substitutes are, namely the availability of internal finance, access to debt or equity financing, or the functioning of the credit market (Fazzari et al. 1988).

The use of internal sources of financing is influenced by its availability and by moral hazard problems and tax considerations. Moral hazard refers to the difficulty in separating the interests of management and ownership, and when the manager's investment strategy does not tie in with the owner's goal of maximizing the firm's value (Hall and Lerner 2010). In such cases, in order to reduce agency cost, ${ }^{2}$ owners can influence the value of the $R \& D$ investment to protect themselves from risk and by limiting access to the use of internal capital (Jensen and Meckling 1976). Tax considerations relate to the fact that debt and retained earnings are taxed differently (Auerbach 1984). For example, debt is tax-deductible at the corporate level (tax savings for interest paid on the debt), whereas using retained earnings as a source of finance could lead to the owner avoiding personal tax on dividends, but the firm's capital gains are still taxed at the corporate level (Hall and Lerner 2010).

Nonetheless, despite the entrepreneur's preference for internal or external sources of finance, after-tax considerations, their choices could also be influenced by credit rationing. Stiglitz and Weiss (1981) were

\footnotetext{
${ }^{2}$ Agency cost refers to the sum of monitoring the owner's expenditure, bonding expenditure by the agent (acting on the owner's behalf), and residual loss (Jensen and Meckling 1976).
} 
among the main contributors in explaining the phenomena of credit rationing, arguing that if rationing exists, it is due to market failures. These authors explained that excessive demand for loans should be solved by an increase in price (interest rate), leading to an adjustment of demand and supply until reaching the market equilibrium. However, imperfect information and adverse selection lead banks to limit the supply because it is difficult for them to identify borrowers who are more likely to repay their loans. So, given the uncertainty about the expected return, due to potential risk, banks prefer to ration the supply of loans, despite the existence of demand.

Consequently, firms can face financing constraints due to the difficulty in accessing external finance but also to the insufficiency or non-availability of internal funds. A major challenge in identifying a financially constrained firm concerns also the nature of the concept, which is more subjective to each firm than empirically observable or directly measurable (Silva and Carreira 2012a).

Fazzari et al. (1988) introduced the sensitivity of investment to cash flow as an indirect measure of financing constraints, on the basis that this indicator can reflect firm liquidity, availability of internal funds for debt repayment and net worth positions, which can also have an impact on the cost of new debt. Despite some criticism and limitations, ${ }^{3}$ this method has been used by many authors to test the effect of financing constraints on the firm's decision to invest, both in traditional tangible assets (Minton and Schrand 1999; Moyen 2004; Fee et al. 2009) and in innovation or R\&D (Himmelberg and Petersen 1994; Bond et al. 2005; Cincera and Ravet 2010; Cincera et al. 2016). Besides cash flow having a positive effect on investment, Himmelberg and Petersen (1994) also defend that its effect on $R \& D$ investment could be higher than on an ordinary investment given their different characteristics (tangibility and collateralization).

A more recent alternative to measuring financing constraints is using survey data (Canepa and Stoneman 2002; Iammarino et al. 2009; D'Este et al. 2012; Coad et al. 2016) or company report information (Hadlock and Pierce 2010). These indicators are built on the results of entrepreneur perception and self-evaluation of financing constraints. Direct measures of financing

\footnotetext{
${ }^{3}$ For more details, see Kaplan and Zingales (1997 and 2000) or Hall et al. (2016) for a survey of the literature.
}

constraints can avoid some bias affecting indirect measures (Hall et al. 2016), but due to the subjective nature of self-assessment, this could also be a potential source of bias (Silva and Carreira 2012b).

The present study focuses on direct assessment of financing constraints through an anonymous survey on SMEs' access to finance in the euro area (SAFE). Ferrando and Mulier (2013), assessing firms' financing constraints using a SAFE database and firms' financial statements, demonstrated that firms which perceived financing constraints have similar characteristics to those faced with an actual situation. So, we can deduce that the potential source of bias due to the selfassessment used for the SAFE database is minimal.

\section{Database and sample selection}

The database comes from the anonymous "Survey on the Access to Finance of SMEs in the euro area" (SAFE). ${ }^{4} \mathrm{SAFE}$ is conducted bi-annually together by the European Central Bank (focusing on large Euro Area countries) and the European Commission (focusing on all EU countries) since 2009. "The companies in SAFE are selected randomly from the Dun \& Bradstreet business register (...). The sample sizes in the different countries were selected based on a trade-off between the costs of the survey at the euro area level and representativeness at the country level" (ECB 2016:6). The inquired firms in SAFE included firms with different ownership: family, entrepreneur, other enterprises, public shareholders, venture capitalist, or business angels, among others. ${ }^{5}$ Since SAFE is anonymous, it is not possible to cross information with other sources.

We used data from the five first round of SAFE, which covers the period from 2014 and 2018. The database is constructed using repeated cross-sectional data. Firms surveyed are located in Euro area countries, other EU Member states, and other countries (such as Albania, the Former Yugoslav Republic of Macedonia, Iceland, Montenegro, and Turkey). Firms are asked to answer, among other topics, about the availability of

\footnotetext{
${ }^{4}$ As regards the main limitations of the study, these are linked with the characteristics of the database used, namely the subjective (selfperception) and categorical nature of the responses (most answers are "yes" or "no"). Additionally, since the survey is anonymous, it is impossible to cross information with other sources, such as AMADEUS and ORBIS.

${ }^{5}$ For more details about sample selection see ECB (2016).
} 
financing and market conditions over the past 6 months, as well as their growth ambitions for the next 3 years, underlining financing obstacles to growth.

The present study focuses on SMEs ${ }^{6}$ located in EU28 that expect to grow and need external finance to carry out their growth ambitions since we have information on SAFE about the main dimensions we want to assess only for this group of firms. Only firms answering that they need external financing to realize their growth ambitions are asked about the most limiting factor in acquiring this finance. Similarly, only firms expecting to grow were asked about the amount of external finance to realize their growth ambitions. Taking into account all these criteria, the initial sample (Figure S1 - Supplement material) comprises 44,573 SMEs located in EU28, which expect to increase their turnover in the next 2 to 3 years and need external finance to do so. However, only 27,546 firms provided a valid answer to all questions on the survey, and these form the sample used in the present study. ${ }^{7}$

\section{Conceptual framework and methodology}

The paper aims at identifying, firstly, which factors on the supply side of financial markets have the highest impact on hindering European firms' access to finance, and, secondly, assessing how far innovative behavior can induce financing constraints. Therefore, the first two steps involve the definition of being financially constrained and being an innovative firm. Innovative firms are those answering in the SAFE questionnaire that they had introduced in the past 12 months a new (or significantly improved) product, service, process, method, management organization, or way of selling goods or services. This classification also corresponds to the Schumpeter (1934) and OECD (2005) definition of an innovative firm. In the present study, the concept of novelty is only related to firm/entrepreneur point of view.

\footnotetext{
${ }^{6}$ The firm size is divided into three categories (micro, small, and medium-sized firms) considering as criteria, the number of employees, as reported in the Commission Recommendation 2003/361.

${ }^{7}$ Table S7 in the supplement material reports the results of simple Probit regression for different samples using only the main firm characteristics, to assess the representativeness of the sub-sample. Results show that even reducing the $60 \%$ the sample there is no differences between them.
}

Concerning firms' financial status of being financially constrained, we used the answer to the question about how great problem access to finance was for their business in the past 6 months. The answer is on a scale of 1 to 10 , where 1 means it is not at all important and 10 means it is extremely important. In order to define the firms' financial status, we need to determine the limit from which firms are considered financially constrained. Authors using the CIS database (Galia and Legros 2004; Canepa and Stoneman 2008; Iammarino et al. 2009), where the degree of importance of obstacles to innovation activities is on a 4-point Likert scale, from 0 (no effect or not relevant) to 3 (high or very important), classified firms as constrained if they responded 2 (important) or 3 (very important). Following this approach and converting the SAFE scale to the CIS scale, we obtain the limit of 7.5 or more precisely of 8 . However, if we observe the mean of the degree of the problem for those firms that considered access to finance as the most pressing of all the problems listed in the survey (Table S2 in Supplement material), these firms reported a score of almost 9 . Therefore, we performed preliminary estimations ${ }^{8}$ using three possibilities for financing constraints, considering the degree of access to finance as an important problem between 7 and 10, 8-10, and 9-10. The model where access to finance is on a scale between 9 and 10 explains the data better, for the reasons that it has higher overall rate of correct classification, pseudo $R^{2}$, and likelihood functions. Therefore, we defined financially constrained firms as those rating the degree of access to finance as a pressing problem at 9 and 10 .

The conceptual framework is based on the fact that innovative behavior can affect access to finance, which consequently could be an obstacle to firm growth ambitions. The underlying dynamic of this process is schematized in Fig. 1, where innovation behavior is observed before or simultaneously to the firms' perception of access to finance as a pressing problem. As innovation behavior is observed before access to finance as a pressing problem, the inverse relationship (impact of financing on innovation) cannot be precisely tested.

Endogeneity represents a major issue when we assess the effect of innovation behavior on whatever firms' reported statement. According to Savignac (2008), the decision to undertake an innovative project is subject to a selective process, and both innovation behavior and

\footnotetext{
${ }^{8}$ Results available upon request.
} 


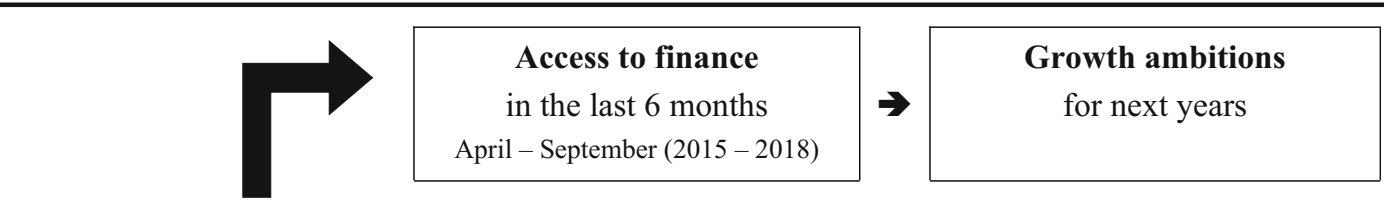

Innovation behavior in the last 12 months

August (2014 - 2017) - September (2015 - 2018)

Fig. 1 Conceptual framework timeline. Source: Authors' own elaboration

financial constraints are affected by common unobservable individual characteristics. One way to deal with unobservable problems is to use a switching simultaneous-equations model, as suggested by Maddala (1983), when selectivity is due to more than one source of bias. An example of this model is the recursive bivariate probit model (RBPM), used by Savignac (2008) and Mancusi and Vezzulli (2014), to assess the effect of financing constraints on the innovation or $\mathrm{R} \& \mathrm{D}$ decision, respectively. The bivariate probit model is based on a probit model with sample selection, following Heckman (1979).

The RBPM adopts a structural approach in which the second equation $\left(y_{2 i}^{*}\right)$ includes the dependent variable of the first equation $\left(y_{1 i}\right)$ as an endogenous variable, and both variables of interest are binary variables. Explanatory variables $\left(x_{i}\right)$ of both equations can have common elements, but also need to have some different exogenous variables in each equation (Maddala 1983). The RBPM assumes that the error terms $\left(\varepsilon_{i}\right)$ are independent and follow a bivariate standard normalization distribution (2). However, the joint estimation of both equations is only required if the correlation coefficient of the two error terms is $\rho \neq 0$, in order to generate consistent estimates.

$\left\{\begin{array}{c}y_{1 i}^{*}=x_{1 i} \beta_{1}+\varepsilon_{1 i}, \quad y_{1 i}=1 \text { if } y_{1 i}^{*}>0 ; 0 \text { otherwise } \\ y_{2 i}^{*}=x_{2 i} \beta_{2}+\theta_{1} y_{1 i}+\varepsilon_{2 i}, \quad y_{2 i}=1 \text { if } y_{2 i}^{*}>0 ; 0 \text { otherwise }\end{array}\right.$

$\left(\begin{array}{l}\varepsilon_{1 i} \\ \varepsilon_{2 i}\end{array}\right) \rightarrow \Phi_{2}\left[\left[\begin{array}{l}0 \\ 0\end{array}\right],\left[\begin{array}{ll}1 & \rho \\ \rho & 1\end{array}\right]\right]$ where $\Phi_{2}$ refers to the bivariate standard normal-distribution function

The $\rho$ also reports the magnitude and direction of bias due to the endogenous nature of $y_{1 i}$ in the second equation. For example, when $\rho>0$ this means that ignoring the endogeneity of $y_{1 i}$ biases the result of the coefficient $\theta_{1}$ upwards in comparison to estimation taking into account the endogeneity of $y_{1 i}$, whereas when $\rho<0$ this implies a downward bias of the results of $\theta_{1}$ when the second equation is estimated ignoring the endogenous nature of $y_{1 i}$ (Chiburis et al. 2011).

The advantage of using a RBPM in comparison with an IV-probit regression is twofold. Firstly, to identify a good instrumental variable with IV-probit is not easy when using cross-sectional data. Secondly, when using an IV-probit, the first equation (endogenous variable) is estimated not only considering the identified instrument, but also all the exogenous variables included in the second equation. Consequently, we are not able to control which instruments to use in the first equation. In the case of a RBPM, we can select which variables will explain each equation, and for this reason, it represents a better option of model estimation considering the purpose of the study.

In the present study, the dependent variable of the first equation $\left(y_{1 i}\right)$, the endogenous variable, refers to firm innovation behavior. The dependent variable of the second equation $\left(y_{2 i}^{*}\right)$ refers to the extent to which firms may be financially constrained. Explanatory variables included in the first equation refer to determinants of innovation activities (Scherer 1965; Crépon et al. 1998; Smolny 2003; Savignac 2008), namely firm characteristics (size, age, type of ownership, and international position of sales) and the degree of competition (proxy for market power).

The second equation is based on the model of Aghion et al. (2004), where being a financially constrained firm is explained by innovation behavior and firms' characteristics. According to the literature, firm characteristics include size, age, type of ownership, activity sector, 
international position of sales, and firms' liquidity indicators (decrease of sales and increase of cost and increased own capital). We also add to the model other factors able to explain the dependent variable, such as factors in the financial market limiting future finance for growth, and the importance of factors for future financing. As regards these last groups of explanatory variables, they included factors explaining market conditions in the financial market, namely obstacles and limitations identified by firms, which could influence future financing and explain the financing constraints. These explanatory variables include factors that can be considered as problems on the supply side (such as collateral requirement, price, and bureaucracy) and variables that reflect potential solutions (important factors to obtain future financing) to facilitate access to finance. A positive relationship between these explanatory variables and the dependent variable (to be financially constrained) could indicate that the more important an obstacle for future financing, the more difficult it is for a firm to access external finance. On the other hand, a negative relationship between these explanatory variables and the variable of interest could indicate that policy intervention in this area or for this kind of firm is less relevant. Both equations also included country and industry fixed effects, which allow capturing the demand for external finance. For more details about variables' definition see Table S1 in Supplement material.

One possible answer to the question "what is the most limiting factor to get future finance to realize growth ambitions" in SAFE is "financing nonavailable at all." Due to a potential tautological ${ }^{9}$ issue between this variable and the dependent variable of being financially constrained, we excluded all firms that selected this factor, since the answer provided by firms to that question is exclusive, i.e., firms can only identify one limiting factor as an answer to this question.

A main assumption of the present analysis is that future expectations in terms of financial needs can be used to predict whether the current access to finance represents a pressing problem. In order to test this hypothesis, a preliminary analysis based on a univariate probit ${ }^{10}$ confirmed that the firm's present financial

\footnotetext{
${ }^{9}$ By tautological relationship, we mean that $x$ does not cause $y$ (noncausal relationship) since $x$ is just another way to reflect the same statement reported by $y$.

${ }^{10}$ Results available upon request.
}

condition can influence future expectations in terms of access to finance, and consequently, we could expect the inverse relationship also to be true. ${ }^{11}$

Furthermore, as a complementary analysis, we reproduced the same exercise by innovation strategy (simple and complex innovation ${ }^{12}$ ) and typology (product, process, organization or marketing innovation). Lastly, we estimated two univariate probit models for firms that reported beeing financially constrained, one with a sub-sample composed only of innovative firms and a second with only non-innovative ones. The aim is to assess differences as regards firms' perception of the characteristics of the supply side of the financial market.

All regression estimations are weighted, ${ }^{13}$ in order to control for firms' characteristics (size, industry sector and country) representativeness in their country and in the EU. We used the weight variable present in the SAFE database, where the weight of each enterprise is adjusted in each size class, economic sector, and country.

\section{Results and discussion}

5.1 Sample description: financially constrained vs. non-constrained firms

Table S2 in supplement material reports the distribution of the sample by firm characteristics and financial indicators. The sample is composed of micro (32\%), small (34\%), and medium-sized firms (34\%). Around $80 \%$ are more than 5 years old. Regarding the distribution by sector, all categories are quite well represented, despite a higher proportion of services to businesses or individuals $(38 \%)$ and a smaller one for the construction sector (11\%). Nearly $54 \%$ of firms sold their goods and/or services in foreign markets in the previous year.

\footnotetext{
${ }^{11}$ This preliminary analysis revealed that a one-unit increase in the degree of perceiving access to finance as a pressing problem leads to an increase in the likelihood of perceiving future financing as not available by $2.3 \%$ and being financially constrained at present increases by $15.5 \%$ the probability of perceiving future financing as not available.

${ }^{12}$ Simple innovation means that firms introduce only one type of innovation among the four listed, whereas a complex innovation strategy corresponds to the introduction of more than one type of innovation.

${ }^{13}$ As robustness tests (results available under request), we estimated a non-weighted regression, and the results obtained with and without the use of sampling weight are almost the same. Despite some differences in the size of coefficient, the conclusions are the same.
} 
About $64 \%$ of the respondents have launched at least one type of innovation ${ }^{14}$ in the market or their own organization (such as a new process, work restructuring, or new way of selling) (Table S3 in supplement material). More than half of innovative companies have adopted a complex innovation strategy, introducing two or more innovation types among the four listed. Product innovation is the typology the most frequently introduced by firms in the market (39\%), while, marketing innovation is the least one $(28 \%)$. Concerning differences between innovation behavior by sector, Table S4 in the supplement material reveals that firms operating in industry sector are more innovative as regards to innovation strategy and typology, except for marketing innovation, which is more frequent in firms operating in trade and services sectors. Firms located in North and South of Europe report a higher likelihood to be innovative and a higher propensity to implement a complex innovation than firms in Central Europe.

Financially constrained firms and non-financially constrained ones (Tables S2 and S3 - supplement material) show significant differences in almost all categories. Innovative, smaller, and younger firms are more frequently financially constrained. Nearly $39 \%$ of the observed firms have increased their own capital in the last 6 months, and non-financially constrained firms show a higher growth of their own capital in comparison with their counterparts. Around $8 \%$ of the sample have experienced in the last 6 months, a simultaneous decrease in turnover and an increase in costs; however, it seems that non-statistical differences between groups exist.

Approximately $44 \%$ of the sampled firms reported no obstacles for obtaining future financing to realize their growth ambitions, despite around $23 \%$ of them declared to be financially constrained. Insufficient collateral or guarantee $(17 \%)$ and too high interest rate or price (15\%) were the two most commonly obstacles reported by firms. Differences of means between financially constrained and non-constrained firms are observed in all limiting and important factors to get future financing.

\footnotetext{
${ }^{14}$ This proportion of innovative firms is a little higher than the percentage of innovative firms in the last Community Innovation Survey (CIS) of $49 \%$, but if we consider the whole sample, this value is closer to the 2014 CIS, with a representativeness of $60 \%$. This finding suggests that in the group of firms with growth ambitions, there is a higher proportion of innovative firms.
}

5.2 Interpretation of model estimations: financing constraints for growth ambitions

Starting with the estimation of a univariate probit model where innovation behavior is considered an exogenous variable (column 3 in Table S8 - supplement material), we observe that being an innovative firm has a positive and significant effect on the probability of being financially constrained. Nevertheless, when testing for endogeneity of innovation behavior, including those in an equation system composed of two probit models (first equation referring to innovation behavior and the second to the probability of being financially constrained), the results of RBPM estimation (Table 1) show a significant negative correlation between the errors of both equations $(\rho=-0.79)$. This conclusion means that to obtain consistent estimators, both probit equations need to be estimated jointly, in order to control for endogeneity bias.

The negative value of $\rho$ also means that the existing bias due to endogeneity lowers the effect of innovation behavior on the firm's financial statement of being financially constrained. This assumption is confirmed when we compare the results of the coefficients of innovation behavior obtained with the univariate prob$\mathrm{it}^{15}(\beta=0.0895)$ and the recursive bivariate probit $(\beta=$ 1.351). This difference reveals that unobservable firm characteristics affecting both equations and the selection process play a vital role and need to be considered to reduce potential bias.

The multicollinearity diagnostic (Table S6 in supplement material) performed using a correlation matrix shows that our independent variables are not correlated with each other, leading to precise estimation.

Regarding the suitability of the first equation, column (1) of Table 1 shows that our exclusion restriction (competition pressing problem) is statistically significant and the explanatory variables are the expected signs. Competition, being equity-backed firms and the presence in international markets (exporter) have a positive impact on the likelihood to innovate. Larger and younger firms are also more likely to innovate, in line with scientific literature. As results of eq. 1 are consistent, it could be considered as a good predictor of innovation behavior, which affects the probability of being financially constrained.

The results of the second equation reveal that after controlling for endogeneity and firms' characteristics,

\footnotetext{
${ }^{15}$ Not reported, but available upon request.
} 
being an innovative firm has a positive and significant effect on being financially constrained and increases the probability of having difficulties in accessing external finance by $32 \%$, everything else being equal. This result is also in line with the conclusions of Lee et al. (2015), who found that being an innovative firm increases the probability of facing strong credit rationing between 20 and $40 \%{ }^{16}$

As expected and in line with Savignac (2008) and Coad et al. (2016), external financing constraints decrease if firms have improved their capital provided by owners or shareholders, and if firms sold their goods and services in the international market. For instance, being an exporter decreases by $3.6 \%$, the probability of being a financially constrained firm.

Nevertheless, no significant evidence was found concerning the effect of different types of ownership, firm age and size ${ }^{17}$ and the loss of cash flow due to a simultaneous decrease of turnover and an increase of costs on the likelihood of being financially constrained.

Regarding the main factors limiting future financing for firms' growth ambitions, the results of marginal effects (column 6 in Table 1) illustrate that firms' insufficient collateral or guarantee $(10 \%)$, bureaucracy $(5.8 \%)$, and too high an interest rate or price $(5.2 \%)$ are the factors with the highest impact on the probability of being financially constrained. ${ }^{18}$

Concerning the degree of importance of factors for firms' financing in the future, marginal effects of RBPM show that guarantees for loans $(1.1 \%)$, making existing public measures easier to obtain $(0.064 \%)$ and measures to facilitate equity investment $(0.6 \%)$ have the highest impact on the probability of being financially constrained. Business support services for firms do not appear to be a significant factor explaining the dependent variable. Tax incentives are among the factors with

\footnotetext{
${ }^{16}$ Lee et al. (2015) assessed firms' difficulties in accessing finance using as dependent variables: (i) having difficulties in obtaining financing; (ii) not receiving all the financing requested in the application; (iii) not receiving any finance from first or any source. In order to compare results, we estimated the marginal effect on the basis of the coefficient reported in the mentioned paper for "not receiving any financing after application submission," because this situation refers to stronger credit rationing than not receiving all of what was requested or simply finding trouble in receiving financing.

${ }^{17}$ Even if the scientific literature highlighted that smaller and younger firms are more financially constrained, in the present analysis both variables are non-significant, probably because other indicators capture firm size and age effects.

${ }^{18}$ Compared to a situation with no obstacles, excluding the category of other factors not listed (9.3\%).
}

the lowest significant positive effect, despite this factor being the one with the highest score reported by surveyed firms. This may reveal that although important, this instrument is not the most relevant to solve the problem of financing constraints.

A cross-country analysis (Fig. 2) shows that in EU28 the average probability of being financially constrained for firms with growth ambitions is 5.6\%. Firms located in Cyprus (20.7\%), Greece (18.5\%), and Romania $(12.5 \%)$ are much more constrained than the EU average, whereas those in Luxembourg (1.9\%), Slovakia (2.5\%), and Estonia (3.1\%) are less constrained.

\subsection{Complementary analysis: assessing differences regarding innovation strategy}

As a complementary analysis, we performed the same exercise by innovation strategy and typology. The results of the RBPM are reported in Table S9 in the supplement material. Table 2 displays the marginal effect of innovation behavior, showing that both innovation strategy (simple and complex) and all the four typologies have a positive and significant effect on being financially constrained. Their marginal effect range between 20.7 and $28.7 \%$. The results of the $Z$-test to assess differences between coefficients reveal that firms introducing a complex innovation are more financially constrained than that gambling for a simple innovation strategy. Regarding differences between the innovation typologies no statistical differences were found.

Lastly, to assess differences between innovative and non-innovative firms concerning the determinants of financing constraints, we also estimated a univariate probit regression for being financially constrained for each group. The marginal effects of the main explanatory variables under analysis are displayed in Table 3.

Regarding the main factors limiting future financing for firms' growth ambitions, for both innovative and non-innovative ones, firms' insufficient collateral or guarantee is the factor with the highest impact on the probability of being financially constrained, compared to a situation with no obstacles. Excluding the category of other factors not listed, all the factors do not affect differently both groups.

Concerning the importance of different factors in obtaining future financing, for both groups guarantees for loans, making existing public measures easier to obtain and measures to facilitate equity investments 
Table 1 Results of recursive bivariate probit model

\begin{tabular}{|c|c|c|c|c|c|c|}
\hline \multirow[t]{2}{*}{ Variables } & \multicolumn{3}{|c|}{ Equation 1: being an innovation firm } & \multicolumn{3}{|c|}{ Equation 2: being financially constrained } \\
\hline & $\begin{array}{l}\text { Coeff. } \\
\text { (1) }\end{array}$ & $\begin{array}{l}\text { Std. err. } \\
\text { (2) }\end{array}$ & $\begin{array}{l}\mathrm{dy} / \mathrm{dx} \\
(3)\end{array}$ & $\begin{array}{l}\text { Coeff. } \\
(4)\end{array}$ & $\begin{array}{l}\text { Std. err. } \\
\text { (5) }\end{array}$ & $\begin{array}{l}\mathrm{dy} / \mathrm{dx} \\
(6)\end{array}$ \\
\hline Innovative firm & - & - & & $1.351 * * *$ & $(0.053)$ & 0.319 \\
\hline Size: micro & $-0.085^{* * *}$ & $(0.021)$ & -0.031 & 0.036 & $(0.024)$ & 0.009 \\
\hline Age: old firm & $-0.176^{* * *}$ & $(0.024)$ & -0.064 & -0.023 & $(0.027)$ & -0.005 \\
\hline Ownership: public & 0.072 & $(0.064)$ & 0.026 & -0.099 & $(0.068)$ & -0.023 \\
\hline Ownership: VC and BA & $0.233 * *$ & $(0.112)$ & 0.085 & -0.070 & $(0.116)$ & -0.016 \\
\hline Exporter & $0.270 * * *$ & $(0.020)$ & 0.099 & $-0.153 * * *$ & $(0.025)$ & -0.036 \\
\hline Competition & $0.033 * * *$ & $(0.004)$ & 0.012 & - & - & \\
\hline Dec. turnover and inc. costs & - & - & - & 0.009 & $(0.026)$ & 0.002 \\
\hline Increase own capital & - & - & - & $-0.037 *$ & $(0.021)$ & -0.009 \\
\hline Obstacle: collateral & - & - & - & $0.424 * * *$ & $(0.031)$ & 0.100 \\
\hline Obstacle: price & - & - & - & $0.222 * * *$ & $(0.031)$ & 0.052 \\
\hline Obstacle: loss of control & - & - & - & $0.095^{*}$ & $(0.052)$ & 0.022 \\
\hline Obstacle: bureaucracy & - & - & - & $0.247 * * *$ & $(0.036)$ & 0.058 \\
\hline Obstacle: other & - & - & - & $0.394 * * *$ & $(0.034)$ & 0.093 \\
\hline Importance: guarantees for loans & - & - & - & $0.0461 * * *$ & $(0.004)$ & 0.011 \\
\hline Importance: easier access to equity & - & - & - & $0.025^{* * * *}$ & $(0.004)$ & 0.006 \\
\hline Importance: export credit & - & - & - & $0.011 * * *$ & $(0.004)$ & 0.002 \\
\hline Importance: tax incentives & - & - & - & $0.012 * *$ & $(0.005)$ & 0.003 \\
\hline Importance: business support services & - & - & - & 0.005 & $(0.005)$ & 0.001 \\
\hline Importance: easier access pub. measures & - & - & - & $0.027 * * *$ & $(0.005)$ & 0.006 \\
\hline Activity, country and wave dummy & Yes & & & Yes & & \\
\hline Constant & $0.320 * * *$ & $(0.061)$ & & $-2.618 * * *$ & $(0.080)$ & \\
\hline Observations & 27,546 & & & 27,546 & & \\
\hline Log-likelihood functions & & & & $-19,036.5$ & & \\
\hline Wald test $-H 0$ : all coefficients $=0$ & & & & 0.000 & & \\
\hline Coefficient correlation: rho & & & & -0.791 & & \\
\hline Wald test- $H 0:$ rho $=0$ & & & & 0.000 & & \\
\hline
\end{tabular}

Authors' own elaboration based on SAFE database (2014-2018)

Weighted regression. Robust standard errors in parentheses. Significance: $* * * p<0.01, * * p<0.05$, $* p<0.1$ Reference category for firm size: small and medium; for age: young and mature; for main ownership: all other categories (one or more individuals, other enterprises and others not listed); for obstacles: no obstacles

are the most relevant factors. Furthermore, for innovative firms the first two (guarantees for loans and public support) report even a higher effect in comparison with non-innovative ones, once their coefficients are statistically different.

For both groups, the importance of tax incentives displays the smallest effect in comparison with the other significant variable in this category. These findings suggest that on the one hand, firms for which tax incentives are a relevant factor in future financing are less financially constrained, perhaps because this policy measure implies financial compensation for an investment, or an expenditure already made. Hence, firms have a priori financial resources to do so. On the other hand, considering that financing constraints are essentially linked with liquidity problems, the lesser importance of tax incentives could be due to the inappropriate use of this instrument in all stages of the firm's life and product cycle. Indeed, tax incentives for R\&D provide financial support at the starting point of the innovation process, but do not help firms in the next steps, to place innovation in the market. ${ }^{19}$ To obtain financial resources for

\footnotetext{
${ }^{19}$ Firms' additional current expenditure linked with the introduction of innovation in the market, such as the cost of purchasing raw materials is not an eligible cost (for more details, see the framework for State aid for R\&D and innovation-EC 2014).
} 


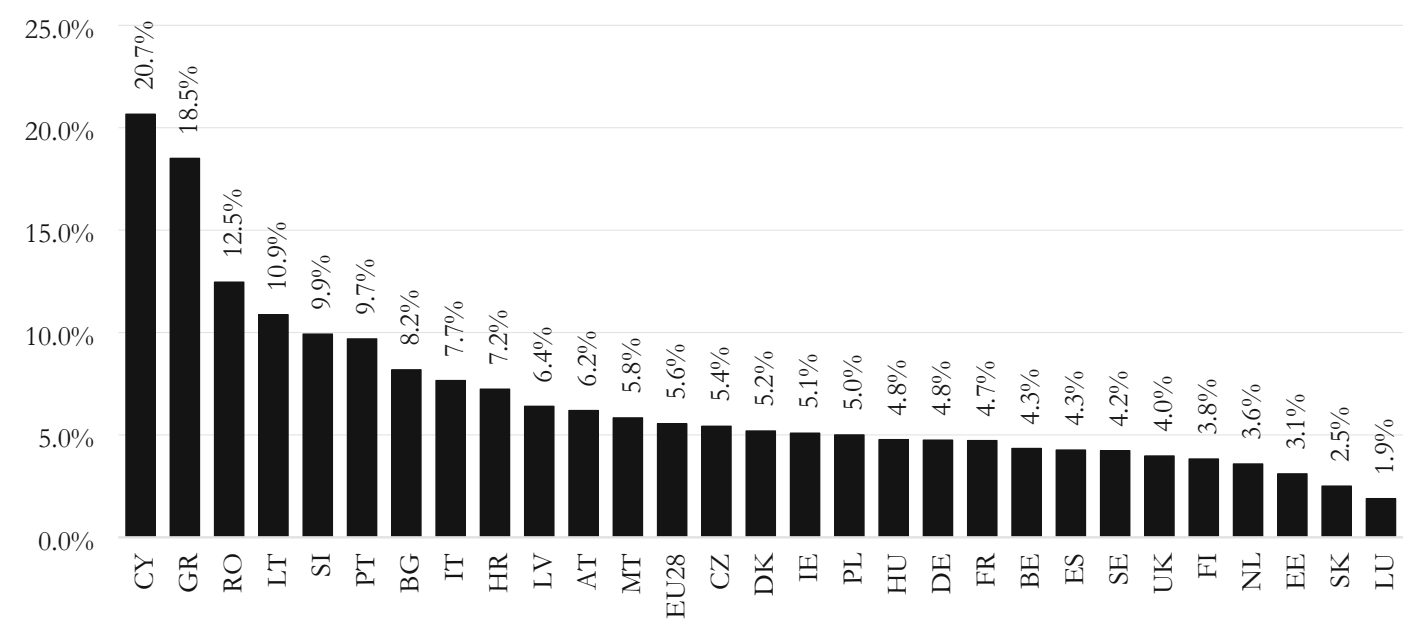

Fig. 2 Average probability of innovative firm to be financially constrained, by country. Authors' own elaboration based on SAFE database. Results refer to descriptive statistics (weighted mean) by

cash flow, firms can usually resort to a credit line or bank overdraft. However, a recent study (Cincera and Santos 2018) showed that innovative firms, due to their riskier activities, have to pay a higher interest rate and are more likely to see the collateral requirement increased than non-innovative firms. These conclusions are in line with the findings of the present study, where guarantees for loans are one of the main causes of firms' problems in accessing finance. country of the estimated probability of being financially constraints and to be an innovative firm. Figure S2 in supplement material shows the geographical distribution of the sample.

\section{Conclusion and policy recommendations}

The present study presents a direct assessment of financing constraints through the anonymous survey of SMEs in the euro area (SAFE) as regards access to finance. Using a recursive bivariate probit model, the paper contributes to the literature, firstly by identifying which factors on the supply side of the financial market have the most impact on hindering firms' access to finance

Table 2 Marginal effect of innovation strategy and typology: effect of innovation behavior on being financially constrained (results of RBPM)

\begin{tabular}{|c|c|c|c|c|}
\hline Variables & $\mathrm{dy} / \mathrm{dx}$ & Std. err. & $z$ & $P>z$ \\
\hline Simple Innovation & 0.207 & 0.029 & 7.08 & 0.0000 \\
\hline Complex Innovation & 0.284 & 0.024 & 11.69 & 0.0000 \\
\hline Product Innovation & 0.229 & 0.034 & 6.80 & 0.0000 \\
\hline Process Innovation & 0.211 & 0.042 & 5.07 & 0.0000 \\
\hline Organization Innovation & 0.287 & 0.022 & 13.33 & 0.0000 \\
\hline Marketing Innovation & 0.273 & 0.023 & 12.09 & 0.0000 \\
\hline \multicolumn{5}{|c|}{ Results $Z$-test differences between coefficients } \\
\hline Simple vs. complex innovation & & & 2.01 & 0.0442 \\
\hline Product vs. process innovation & & & 0.34 & 0.7340 \\
\hline Product vs. organization innovation & & & 1.45 & 0.1467 \\
\hline Product vs. marketing innovation & & & 1.08 & 0.2817 \\
\hline Process vs. organization innovation & & & 1.63 & 0.1038 \\
\hline Process vs. marketing innovation & & & 1.31 & 0.1913 \\
\hline Organization vs. marketing innovation & & & 0.46 & 0.6447 \\
\hline
\end{tabular}

Authors' own elaboration based on SAFE database (2014-2018)

Results refer to marginal effect of innovation variable included in the RBPM of Table S9 in supplement material 
Table 3 Marginal effects of probit model: being financially constrained, by innovation behavior

\begin{tabular}{|c|c|c|c|c|c|c|}
\hline \multirow[t]{2}{*}{ Variables } & \multicolumn{2}{|c|}{ Innovative firm } & \multicolumn{2}{|c|}{ Non-innovative firm } & \multicolumn{2}{|l|}{$Z$-test } \\
\hline & $\mathrm{dy} / \mathrm{dx}$ & & $\mathrm{dy} / \mathrm{dx}$ & & $z$ & $P>z$ \\
\hline Obstacle: collateral & 0.102 & $* * *$ & 0.090 & $* * *$ & 1.063 & 0.288 \\
\hline Obstacle: price & 0.055 & $* * *$ & 0.038 & $* * *$ & 1.431 & 0.152 \\
\hline Obstacle: loss of control & 0.040 & $* * *$ & 0.023 & & 0.688 & 0.491 \\
\hline Obstacle: bureaucracy & 0.062 & $* * *$ & 0.050 & $* * *$ & 0.867 & 0.386 \\
\hline Obstacle: other & 0.102 & $* * *$ & 0.072 & $* * *$ & 2.427 & 0.015 \\
\hline Importance: guarantees for loans & 0.012 & $* * *$ & 0.009 & $* * *$ & 1.747 & 0.081 \\
\hline Importance: easier access to equity & 0.006 & $* * *$ & 0.006 & $* * *$ & 0.414 & 0.679 \\
\hline Importance: export credit & 0.004 & $* * *$ & 0.001 & & 1.341 & 0.180 \\
\hline Importance: tax incentives & 0.003 & $* *$ & 0.003 & $* *$ & 0.013 & 0.989 \\
\hline Importance: business support services & 0.001 & & 0.003 & $* *$ & 0.800 & 0.424 \\
\hline Importance: easier access to public measures & 0.008 & $* * *$ & 0.004 & $* * *$ & 2.105 & 0.035 \\
\hline Firms' characteristics & YES & & YES & & & \\
\hline Firms' liquidity indicators & YES & & YES & & & \\
\hline Activity, country, and wave dummy & YES & & YES & & & \\
\hline Log-likelihood functions & -6157.19 & & -2881.8 & & & \\
\hline Pseudo $R^{2}$ & 0.1146 & & 0.1175 & & & \\
\hline Number of observations & 17,532 & & 10,014 & & & \\
\hline
\end{tabular}

Authors' own elaboration based on SAFE database

Robust standard errors in parentheses. Significance: $* * * p<0.01, * * p<0.05, * p<0.1$. Complete results available upon request. The reference category for obstacle to future financing it is no obstacles

and secondly assessing how far innovative behavior can induce financing constraints.

The results show that some firms are more constrained and have more difficulties in accessing external finance. Both internal and external factors affect firms' access to financing.

Innovative firms are more constrained and are between 21 and $32 \%$ more likely to be financially constrained than their non-innovative counterparts.

Concerning characteristics of the supply side of the financial market, insufficient collateral, too much paperwork is involved and too high-interest rate appear to be the most important factors limiting access to future finance. Besides, guarantees for loans, easier access to equity financing, and to direct public support are revealed to be the best solutions to alleviate firms' financing constraints. In fact, the last two instruments are alternatives to traditional bank debt, usually risk adverse and with a high collateral requirement. On the other hand, tax incentives (indirect public support) seem to be the least relevant factor in alleviating firms' financing constraints. A possible explanation for this finding could be that this policy measure implies a financial compensation for an investment or expenditure already made, so firms have a priori financial resources to do so. To obtain financial resources for cash flow, firms can usually resort to a credit line, but this short-term debt is also associated with the need for guarantees, so an alternative solution to finance cash flow with no collateral is to ask an equity investor for support.

All these conclusions open up new suggestions for policymakers. As a complement to direct or indirect support for R\&D and innovation (more focused on investment in fixed assets), innovative companies also need financial support for daily activities. Launching a new product on the market has not only new production costs but also implies higher working capital needs, in order to pay suppliers and workers while the company finds new customers or markets and generates liquidity. Making venture capital operations easier, providing access to credit lines or secured loans could be complements to direct and indirect support to reduce the financing pressure on innovative firms in Europe. 
Supplementary Information The online version contains supplementary material available at https://doi.org/10.1007/s11187021-00449-w.

Acknowledgements The authors are grateful to the European Central Bank (ECB) for the statistical data provided. Acknowledgement goes also to the participants in the 7th ZEW/MaCCI Conference (Mannheim, Germany), CONCORDi 2017 (Seville, Spain) and 22éme Congrès des Economistes (Brussels, Belgium), as well as to Marius Berger (University of Mannheim), Maria Luisa Mancusi (Università Cattolica), Pierre Mohnen (Maastricht University), Bruno van Pottelsberghe (Université libre de Bruxelles), Julien Ravet (Université libre de Bruxelles) and the two anonymous referees for the valuable comments.

Funding This research has received funding from the European Union's Horizon 2020 research and innovation programme under grant agreement No 645884 .

\section{Compliance with ethical standards}

Conflict of interest The authors declare that they have no conflict of interest.

Disclaimer The views expressed are purely those of the author and may not in any circumstances be regarded as stating an official position of the European Commission.

Open Access This article is licensed under a Creative Commons Attribution 4.0 International License, which permits use, sharing, adaptation, distribution and reproduction in any medium or format, as long as you give appropriate credit to the original author(s) and the source, provide a link to the Creative Commons licence, and indicate if changes were made. The images or other third party material in this article are included in the article's Creative Commons licence, unless indicated otherwise in a credit line to the material. If material is not included in the article's Creative Commons licence and your intended use is not permitted by statutory regulation or exceeds the permitted use, you will need to obtain permission directly from the copyright holder. To view a copy of this licence, visit http://creativecommons.org/licenses/by/4.0/.

\section{References}

Aghion, P., Bond, S., Klemm, A., \& Marinescu, I. (2004). Technology and financial structure: Are innovative firms different? Journal of the European Economic Association, 2(2-3), 277-288. https://doi.org/10.1162 /154247604323067989.

Auerbach, A. J. (1984). Taxes, firm financial policy, and the cost of capital: An empirical analysis. Journal of Public Economics, 23, 27-57. https://doi.org/10.1016/0047-2727 (84)90066-5.
Bah, R., \& Dumontier, P. (2001). R\&D intensity and corporate financial policy: Some international evidence. Journal of Business Finance and Accounting, 28(5-6), 671-692. https://doi.org/10.1111/1468-5957.00389.

Belin, J., Cavaco, S. \& Guille, M. (2011). Structure financière et dépenses de R\&D. Economie \& Prévision 2011/1, 197-198, 129-143. DOI: https://doi.org/10.3406/ecop.2011.8082.

Blazy, R., \& Weill, L. (2013). Why do banks ask for collateral in SME lending? Applied Financial Economics, 23(13), 11091122. https://doi.org/10.1080/09603107.2013.795272.

Bond, S., Harhoff, D., \& Van Reenen, J. (2005). Investment, R\&D and financial constraints in Britain and Germany. Annales d'Économie et de Statistique, 79(80), 433-460. https://doi. org/10.2307/20777584.

Canepa, A. \& Stoneman, P. (2002). Financial constraints on innovation: A European cross country study, University of Warwick. EIFC - Technology and Finance Working Papers n. ${ }^{\circ} 02-11$, p. 41.

Canepa, A., \& Stoneman, P. (2008). Financial constraints to innovation in the UK: Evidence from CIS2 and CIS3. Oxford Economic Papers, 60(4), 711-730. https://doi. org/10.1093/oep/gpm044.

Chiburis, R.C., Das, J. \& Lokshin, M. (2011). A practical comparison of the bivariate probit and linear IV estimators. Policy Research Working Paper 5601, the World Bank, p. 44.

Cincera, M., \& Ravet, J. (2010). Financing constraints and R\&D investments of large corporations in Europe and the USA. Science and Public Policy, 37(6), 455-466. https://doi. org/10.3152/030234210X508642.

Cincera, M. \& Santos, A. (2018). "D3.3. Integration in the EcoSystem, WP 3 - Innovation and Access to Finance", Deliverable 3.3. included in the project Investigating the impact of Innovation Union (I3U), Mimeo.

Cincera, M., Ravet, J., \& Veugelers, R. (2016). The sensitivity of R\&D investment to cash flows: Comparing young and old EU and US leading innovators. Economics of Innovation and New Technology, 25(3), 304-320. https://doi.org/10.1080 /10438599.2015.1076201.

Coad, A., Pellegrino, G., \& Savona, M. (2016). Barriers to innovation and firm productivity. Economics of Innovation and New Technology, 25(3), 321-334. https://doi.org/10.1080 /10438599.2015.1076193.

Crépon, B., Duguet, E., \& Mairesse, J. (1998). Research, innovation and productivity: An econometric analysis at the firm level. Economics of Innovation and New Technology, 7(2), 115-158. https://doi.org/10.1080/10438599800000031.

D'Este, P., Iammarino, S., Savona, M., \& von Tunzelmann, N. (2012). What hampers innovation? Revealed barriers versus deterring barriers. Research Policy, 41(2), 482-488. https://doi.org/10.1016/j.respol.2011.09.008.

Damodaran, A. (2006) Applied corporate finance - A user's manual. John Wiley \& Sons, Inc.

EC (2014). Communication from the Commission - Framework for State aid for research and development and innovation (2014/C 198/01). Official Journal of the European Union, C198, 27.6.2014, p. 29.

ECB (2016). Survey on the access to finance of enterprises Methodological information on the survey and user guide for the anonymized micro dataset, European Central Bank, p.33.

Fazzari, S., Hubbard, R. G., \& Petersen, B. C. (1988). Financing constraints and corporate investment. Brookings Papers on 
Economic Activity, 1, 141-206. https://doi.org/10.2307 12534426.

Fee, C. E., Hadlock, C. J., \& Pierce, J. R. (2009). Investment, financing constraints, and internal capital markets: Evidence from the advertising expenditures of multinational firms. The Review of Finance Studies, 22(6), 2361-2392. https://doi. org/10.1093/rfs/hhn059.

Ferrando, A. \& Mulier, K. (2013). Firms' financing constraints Do perceptions match the actual situation?. ECB Working Paper Series 1577, European Central Bank, p. 53.

Galia, F., \& Legros, D. (2004). Complementarities between obstacles to innovation: Evidence from France. Research Policy, 33(8), 1185-1199. https://doi.org/10.1016/j. respol.2004.06.004.

Hadlock, C. J., \& Pierce, J. R. (2010). New evidence on measuring financial constraints: Moving beyond the $\mathrm{KZ}$ index. The Review of Financial Studies, 23(5), 1909-1940. https://doi. org/10.1093/rfs/hhq009.

Hall, B. (2009). The financing of innovative firms. EIB Papers, 14(2), p.22.

Hall, B. \& Lerner, J. (2010). The financing of R\&D and innovation. In B.H. Hall \& N. Rosenberg (Ed.) Handbook of the Economics of Innovation, Vol. 1 (pp. 609-639). Elsevier. https://doi.org/10.1016/S0169-7218(10)01014-2.

Hall, B. H., Moncada-Paternò-Castello, P., Montresor, S., \& Vezzani, A. (2016). Financing constraints, R\&D investments and innovative performances: New empirical evidence at the firm level for Europe. Economics of Innovation and New Technology, 25(3), 183-196. https://doi.org/10.1080 /10438599.2015.1076194.

Heckman, J. (1979). Sample selection bias as a specification error. Econometrica, 47, 153-161. https://doi.org/10.2307 $/ 1912352$.

Himmelberg, C. P., \& Petersen, B. C. (1994). R\&D and internal finance: A panel study of small firms in high-tech industries. Review of Economics and Statistics, 76(1), 38-51. https://doi. org/10.2307/2109824.

Hottenrott, H. \& Peters, B. (2012). Innovative capability and financing constraints for innovation - more money, more innovation?. ZEW Discussion Paper no. 09-081, revised version, p.42.

Iammarino, S., Sanna-Randaccio, F., \& Savona, M. (2009). The perception of obstacles to innovation. Foreign multinationals and domestic firms in Italy. Revue d' Économie Industrielle, $125,75-104$.

Jensen, M. C., \& Meckling, W. (1976). Theory of the firm: Managerial behavior, agency costs, and ownership structure. Journal of Financial Economics, 3, 305-360. https://doi. org/10.1016/0304-405X(76)90026-X.

Jorgenson, D. W. (1963). Capital theory and investment behavior. American Economic Review, 53(2), 247-259 https://www. jstor.org/stable/1823868.

Kaplan, S. N., \& Zingales, L. (1997). Do Investment-cash flow sensitivities provide useful measures of financing constraints? The Quarterly Journal of Economics, 112(1), 169$215 \mathrm{https} / / /$ www.jstor.org/stable/2951280.

Kaplan, S. N., \& Zingales, L. (2000). Investment-cash flow sensitivities are not valid measures of financing constraints. The
Quarterly Journal of Economics, 115(2), 707-712 https://www.jstor.org/stable/2587008.

Lee, N., Sameen, H., \& Cowling, M. (2015). Access to finance for innovative SMEs since the financial crisis. Research Policy, 44(2), 370-380. https://doi.org/10.1016/j. respol.2014.09.008.

Maddala, G. S. (1983). Limited-dependent and qualitative variables in economics. New York: Cambridge University Press.

Mancusi, M. L., \& Vezzulli, A. (2014). R\&D and credit rationing in SMEs. Economic Inquiry, 52(3), 1153-1172. https://doi. org/10.1111/ecin.12080.

Mazzucato, M. (2013). Financing innovation: Creative destruction vs. destructive creation. Industrial and Corporate Change, 22(4), 851-867. https://doi.org/10.1093/icc/dtt025.

Minton, B. A., \& Schrand, C. (1999). The impact of cash flow volatility on discretionary investment and the costs of debt and equity financing. Journal of Financial Economics, 54(3), 423-460. https://doi.org/10.1016/S0304-405X(99)00042-2.

Modigliani, F., \& Miller, M. H. (1958). The cost of capital, corporation finance and the theory of investment. American Economic Review, 48, 261-297.

Moyen, N. (2004). Investment-cash flow sensitivities: Constrained versus unconstrained firms. The Journal of Finance, 59(5), 2061-2092. https://doi.org/10.1111/j.15406261.2004.00692.x.

OECD. (2005). The measurement of scientific and technological activities: Guidelines for collecting and interpreting innovation data: Oslo manual (Third ed.). Paris: OECD Publishing.

Savignac, F. (2008). Impact of financial constraints on innovation: What can be learned from a direct measure? Economics of Innovation and New Technology, 17(6), 553-569. https://doi. org/10.1080/10438590701538432.

Scherer, F. M. (1965). Firm size, market structure, opportunity, and the output of patented inventions. The American Economic Review, 55(5), 1097-1125.

Schumpeter, J.A. (1934). The theory of economic development an inquiry into profits, capital, credit, interest, and the business cycle. Harvard Economic Studies 46, Translated by Redvers Opie.

Silva, F., \& Carreira, C. (2012a). Do financial constraints threat the innovation process? Evidence from Portuguese firms. Economics of Innovation and New Technology, 21(8), 701736. https://doi.org/10.1080/10438599.2011.639979.

Silva, F. \& Carreira, C. (2012b). Measuring firms' financial constraints: A rough guide. Notas economicas 23/46. DOI: https://doi.org/10.14195/2183-203x_36_2.

Smolny, W. (2003). Determinants of innovation behaviour and investment estimates for west-german manufacturing firms. Economics of Innovation and New Technology, 12(5), 449463. https://doi.org/10.1080/1043859022000029230.

Stiglitz, J. E., \& Weiss, A. (1981). Credit rationing in markets with imperfect information. The American Economic Review, 7l(3), 393-410 https://www.jstor.org/stable/1802787.

Publisher's note Springer Nature remains neutral with regard to jurisdictional claims in published maps and institutional affiliations. 